\title{
DEVELOPING ENGLISH MORPHOLOGY MATERIALS FOR UNDERGRADUATE STUDENTS AT ALAUDDIN STATE ISLAMIC UNIVERSITY OF MAKASSAR
}

\author{
S uki r m a n \\ IAIN Palopo \\ sukirmanmarshan.sm@gmail.com
}

\begin{abstract}
The objective of this study was to develop a textbook of English morphology materials. The data was obtained by interviewing the lecturer, analyzing the syllabus used at the university, validating the product to the two experts in English morphology, trying out the product to the users. The data was analyzed qualitatively and descriptively. Furthermore, ten aspects of the product were validated to the experts and tried out the users. The aspects were organization of the materials, instructional objectives, examples, exercises, activities, instruction, coverage of the materials, contents of the materials, language, and summaries. The findings of the try-out indicated that all the aspects were clear, understandable, and not confusing for the students. Also, the product was well-designed and attractive. They were also not too easy and difficult. In addition, they dealt with the objective of the course.
\end{abstract}

Keywords: Developing materials and English morphology

\section{INTRODUCTION}

In the preliminary study, it was found that the teaching of English morphology at Alauddin State Islamic University of Makassar was not successful. It could be seen from the students' scores of the course. Most of the students reached score C-. They also pointed out that this course was one of the most difficult courses they had. In fact, they were not motivated and interested to join the course. It was also found that there was no lecturer who had the expertise in teaching the materials. In addition, it was found that both the students did not have appropriate materials of English morphology dealing with their proficiency and needs. In this case, the existing materials were hard for the students to understand the contents because of the language used. The language was not suitable with the students' English proficiency. They did not also provide adequate examples as well as exercises. In addition, they dealt with general discussion of word formation for all languages such as French, German, and Latin words. The students who did not understand those languages were confused. Therefore, the researcher was encouraged to develop appropriate materials of English morphology in the form of a textbook dealing with students' proficiency, needs, and the objectives of course.

The teaching of English morphology had important roles in developing the students' vocabulary development. One of the instructions could be used in teaching the materials was 
morphological instructions. Some studies showed that morphological instructions provide good contributions to the students' vocabulary development. Nunes, Bryant, and Olson (2003), and Nunes and Bryant (2006) provide experimental evidence that morphological instruction improves the students' words reading and spelling, but they also state that this kind of instruction is still uncommon in schools. Meanwhile, Pressley, Disney, and Anderson (2007: 214) review the evidence for the value of teaching internal context cues (morphological words parts) for vocabulary development. They report that there are some evidence that teaching about morphemes can improve the children's and the adults' ability to infer the meaning of words. Furthermore, Anglin (1993) describes that morphological analysis can be a problem solving for the students to decipher or analyze the meaning of the complex words. In this case, the students use their morphological analysis to understand the meaning of the complex words in order to break them into the components morphemes in terms of bases, prefixes, and suffixes. In brief, these studies show that morphological instruction and analysis are beneficial to promote students' ability in analyzing word structures into the smallest unit of the words, and to evolve their ability to infer the meaning of unfamiliar words.

\section{METHOD}

The research design used in this study was Research and Development (R \& D). The development model used was ADDIE model. It stands for Analysis, Design, Develop, Implement, and Evaluate (McGriff, 2000). The procedures were started from analyzing, designing, developing, implementing, and evaluating the materials.

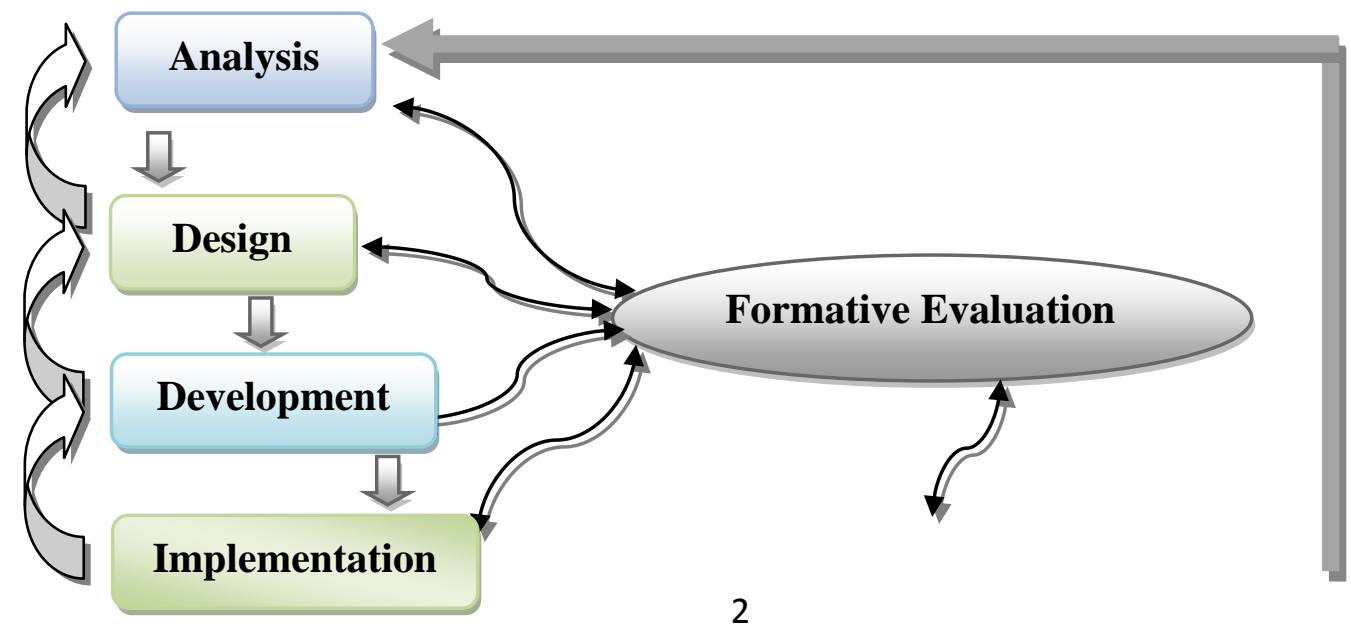




\section{Summative Evaluation}

Figure 2.1. The ADDIE Model (McGriff, 2000)

In analysis phase, the researcher analyzed the syllabus used in order to gain information about the objective of the course and the materials needed by students. After analyzing the objective and the materials, he consulted them to the two experts and the lecturers in order to decide whether the objective should be revised or not as well as whether the materials were appropriate with English formation materials or not.

In design phase, the researcher wrote the objective of the course and selected the delivery materials. After that, he sequenced the materials from easiest to most difficult. Also, he designed the selected materials in the form of a blueprint. In addition, he decided the materials design such as the organization, lay-out, format, style, and font of the product.

In development phase, the researcher developed the materials in the form of a textbook of English morphology. In this case, he discussed the materials based on their order. After that, he provided some examples of each material. Finally, he developed some exercises dealing with the materials - they were developed in varied format.

In implementation phase, the researcher taught the materials to real class. In other words, the materials developed were tried out to the students. The design of the try-out was field tryout. The product was tried out to the fifth semester students at the English Education Department in Alauddin State Islamic University of Makassar. The purpose of this phase was to look at whether the product had fulfilled the learners' needs as well as the objectives of the course or not, and whether the materials were appropriate for the target learners or not. In addition, ten aspects of the product were tried out: organization of the materials, instructional objectives, examples, exercises, activities, instructions, coverage of the materials, contents of the materials, language, and summaries (Ghorbani, 2011and Widyatmoko, 2011).

In evaluation phase, the researcher evaluated the results of the try out. Two kinds of evaluation were involved: formative and summative. Formative evaluation was ongoing during and between phases; meanwhile summative evaluation dealt with summative evaluation dealt with the final evaluation of developed materials.

To obtain valid data, the researcher used two instruments: rubric and worksheet. The rubric was addressed to experts, and students. The worksheet was only addressed to the experts - they were in the forms of worksheet for experts' comment and suggestion as well as the worksheet for experts' revision. Furthermore, Types of data obtained in this study were 
qualitative and quantitative. The qualitative data gained from the experts were analyzed qualitatively; meanwhile the quantitative data gained from the try-out were analyzed descriptively.

\section{FINDINGS AND DISCUSSION}

The results of the needs analysis included the objective and the materials of English morphology. First, the objective of the teaching of English morphology stated in the syllabus was to provide the students with some knowledge of English morphology and how to apply the knowledge for the teaching and learning English. Second, the materials included in the syllabus were 1) introduction, 2) morphemes, 3) root, base, and stem, 4) affixes, 5) inflection and derivation, 6) English words, 7) word formation, and 8) other word formation processes. The results of the product design included writing the objectives of the teaching of English morphology, and the blueprint of English morphology materials. First, the existing objective was consulted to the two experts in order to gain information whether it should be revised or not. They stated that it was a good objective and no needs to be revised - the researcher only rewrote the existing objective. Second, the materials identified in the needs analysis were designed in the form of a blueprint. The contents of the blueprint were designed from easiest to the most difficult.

Two experts were involved in order to validate the product. They validated ten aspects of the product: organization of the materials, instructional objectives, examples, exercises, activities, instruction, coverage of the materials, contents of materials, language, and summary. The product was validated twice. For the first validation, the experts pointed out that seven aspects of the product were developed well, whereas three aspects of them should be revised: language, exercises, and summaries. The language used was confusing; there were some grammatical errors, the exercises were not challenging, and the summaries were too long and not to the point. For the second validation, the experts pointed out that all the aspects of the product was excellent and appropriate with the objective of the teaching of English morphology.

After validation, the ten aspects of the product were tried out to the users. The results of the try-out showed that all the aspects were satisfactory. They were discussed in the following: 
The results of the try-out dealing with the organization of the materials were satisfactory. It was proven by the scores given by the students (see Table1). The data showed that the materials were organized attractively, appropriately, logically as well. The table of qualification indicated that the quality of this aspect was excellent. Therefore, no revision was needed in respect to this aspect.

Table 1 Findings Dealing with the Organization of Materials

\begin{tabular}{|c|c|c|c|c|}
\hline \multirow{2}{*}{ Aspects } & \multirow{2}{*}{ Criteria } & \multicolumn{3}{|c|}{ Percentage (100\%) } \\
\hline & & Yes & Partly & No \\
\hline \multirow{3}{*}{$\begin{array}{l}\text { Organization of } \\
\text { materials }\end{array}$} & $\begin{array}{l}\text { The materials are organized } \\
\text { attractively. }\end{array}$ & $96.67 \%$ & $3.33 \%$ & $0 \%$ \\
\hline & $\begin{array}{l}\text { The organization of the materials } \\
\text { in the form of chapters is } \\
\text { appropriate. }\end{array}$ & $100 \%$ & $0 \%$ & $0 \%$ \\
\hline & $\begin{array}{l}\text { The materials are organized in } \\
\text { logically ordered tasks. }\end{array}$ & $93.33 \%$ & $6.67 \%$ & $0 \%$ \\
\hline
\end{tabular}

Instructional Objectives

The results of the try-out showed that the instructional objectives were clear, understandable, and appropriate. They also reflected the topics. It was proven by the scores given by the students (see Table 2). Table of qualification indicated that the quality of this aspect was excellent. Therefore, no revision was needed in respect to this aspect.

Table 2 Findings Dealing with the Instructional Objectives

\begin{tabular}{clccc}
\hline \multirow{2}{*}{ Aspect } & \multicolumn{1}{c}{ Criteria } & \multicolumn{3}{c}{ Percentage (100\%) } \\
\cline { 3 - 5 } & \multicolumn{1}{c}{ Yes } & Partly & No \\
& $\begin{array}{l}\text { The instructional objectives are clear. } \\
\text { The instructional objectives are }\end{array}$ & $93.33 \%$ & $6.67 \%$ & $0 \%$ \\
Instructional & $\begin{array}{l}\text { understandable. } \\
\text { Objectives }\end{array}$ & $96.67 \%$ & $3.33 \%$ & $0 \%$ \\
& $\begin{array}{l}\text { The instructional objectives are } \\
\text { ordered appropriately. }\end{array}$ & $90 \%$ & $10 \%$ & $0 \%$ \\
& $\begin{array}{l}\text { The instructional objectives reflect to } \\
\text { the topics. }\end{array}$ & $96.67 \%$ & $3.33 \%$ & $0 \%$ \\
\hline
\end{tabular}

\section{Examples}

The results of the try-out dealing with the examples were also satisfactory. The data showed that they were clear, understandable, not too easy and difficult, and not confusing. They also helped students understand the materials and dealt with the theory. It was proven by the scores given by the students (see Table 3). The table of qualification indicated that the quality of this aspect was excellent. Therefore, no revision was needed in respect to this aspect. 
Table 3 Findings Dealing with the Examples

\begin{tabular}{|c|c|c|c|c|}
\hline \multirow{2}{*}{ Aspect } & \multirow{2}{*}{ Criteria } & \multicolumn{3}{|c|}{ Percentage $(100 \%)$} \\
\hline & & Yes & Partly & No \\
\hline \multirow{7}{*}{ Examples } & The examples are clear. & $90 \%$ & $10 \%$ & $0 \%$ \\
\hline & The examples are understandable. & $96.67 \%$ & $3.33 \%$ & $0 \%$ \\
\hline & The examples are too easy. & $96.67 \%$ & $3.33 \%$ & $0 \%$ \\
\hline & The examples are too difficult. & $0 \%$ & $3.33 \%$ & $96.67 \%$ \\
\hline & The examples are confusing. & $0 \%$ & $3.33 \%$ & $96.67 \%$ \\
\hline & $\begin{array}{l}\text { The examples help learners to } \\
\text { understand the materials. }\end{array}$ & $100 \%$ & $0 \%$ & $0 \%$ \\
\hline & The examples deal with the theory. & $96.67 \%$ & $3.33 \%$ & $0 \%$ \\
\hline
\end{tabular}

\section{Exercises}

The results of the try-out dealing with the exercises were also satisfactory. The data showed that they were clear, understandable, and appropriate. They were not confusing and not too easy as well as difficult. In addition, they reinforced what learners had already learned, presented a progression from simple to more complex, varied in format, matched the topic being discussed, and challenged learners. Finally, they helped the learners to comprehend the materials, to enhance their ability to understand the theory of word-structure, to improve their ability in analyzing word-structure, and to enhance their ability in creating English word. In addition, it was proven by the scores given by the students (see Table 4). The table of qualification indicated that the quality of this aspect was also excellent. Therefore, no revision was needed in respect to this aspect.

Table 4 Findings Dealing with the Exercises

\begin{tabular}{|c|c|c|c|c|}
\hline \multirow{2}{*}{ Aspect } & \multirow{2}{*}{ Criteria } & \multicolumn{3}{|c|}{ Percentage $(100 \%)$} \\
\hline & & Yes & Partly & No \\
\hline \multirow{9}{*}{ Exercises } & The exercises are understandable. & $93.33 \%$ & $6.67 \%$ & $0 \%$ \\
\hline & The exercises are clear. & $93.33 \%$ & $6.67 \%$ & $0 \%$ \\
\hline & The exercises are too easy. & $13.33 \%$ & $20 \%$ & $66.67 \%$ \\
\hline & The exercises are too difficult. & $16.67 \%$ & $66.67 \%$ & $16.67 \%$ \\
\hline & The exercises are appropriate. & $93.33 \%$ & $6.67 \%$ & $0 \%$ \\
\hline & $\begin{array}{l}\text { The exercises reinforce what learners } \\
\text { have already learned. }\end{array}$ & $96.67 \%$ & $3.33 \%$ & $0 \%$ \\
\hline & $\begin{array}{l}\text { The exercises present a progression } \\
\text { from simple to more complex. }\end{array}$ & $93.33 \%$ & $6.67 \%$ & $0 \%$ \\
\hline & The exercises are varied in format. & $93.33 \%$ & $6.67 \%$ & $0 \%$ \\
\hline & $\begin{array}{l}\text { The exercises match with the topic } \\
\text { being discussed. }\end{array}$ & $93.33 \%$ & $6.67 \%$ & $0 \%$ \\
\hline
\end{tabular}




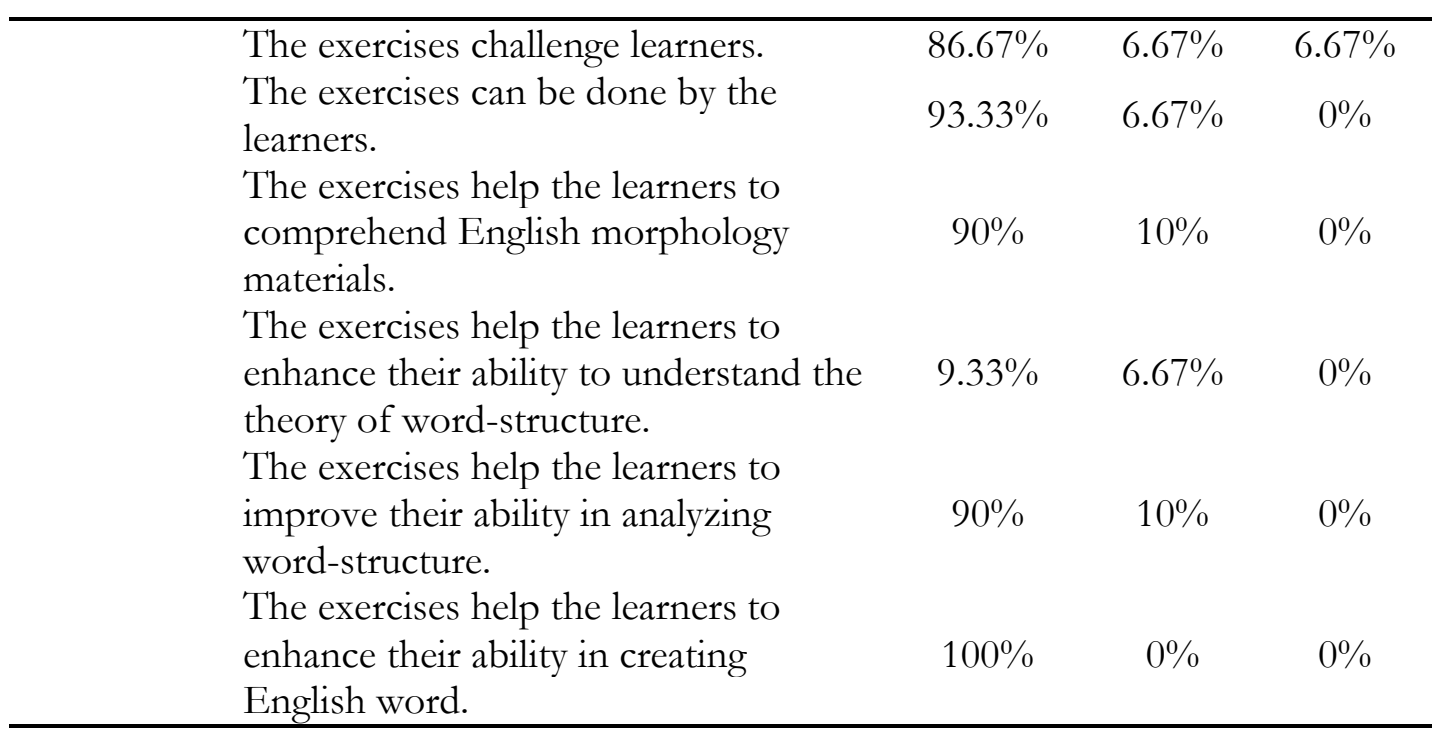

\section{Activities}

The results of the try-out dealing with the activities were also satisfactory. The data showed that they were attractive, and appropriate. They motivated learners, were designed either for group or individual work, were able to be done by the learners, and varied in format. It was proven by the scores given by the students (see Table 5). The table of qualification indicated that the quality of this aspect was also excellent. Therefore, no revision was needed in respect to this aspect.

Table 5 Findings Dealing with the Activities

\begin{tabular}{llccc}
\hline \multirow{2}{*}{ Aspect } & \multicolumn{1}{c}{ Criteria } & \multicolumn{3}{c}{ Percentage (100\%) } \\
\cline { 2 - 4 } & & Yes & Partly & No \\
& The activities are attractive. & $90 \%$ & $10 \%$ & $0 \%$ \\
The activities are appropriate with the & $93.33 \%$ & $6.67 \%$ & $0 \%$ \\
$\begin{array}{l}\text { Students' ability. } \\
\text { The activities motivate learners. }\end{array}$ & $100 \%$ & $0 \%$ & $0 \%$ \\
$\begin{array}{l}\text { The activities are designed for work } \\
\text { The }\end{array}$ & $83.33 \%$ & $10 \%$ & $6.67 \%$ \\
& $\begin{array}{l}\text { group. } \\
\text { The activities are designed for individual. }\end{array}$ & $13.33 \%$ & 66.67 & $20 \%$ \\
& $\begin{array}{l}\text { The activities can be done by the } \\
\text { Tearners. }\end{array}$ & $100 \%$ & $0 \%$ & $0 \%$ \\
The activities are varied in format. & $100 \%$ & $0 \%$ & $0 \%$ \\
\hline
\end{tabular}

\section{Instructions}

The results of the try-out dealing with the instructions were also satisfactory. The data showed that they were clear, appropriate, understandable, not confusing, not ambiguous, and able to be done by the learners. It was proven by the scores given by the students (see Table 
6). The table of qualification indicated that the quality of this aspect was excellent. Therefore, no revision was needed in respect to this aspect.

Table 6 Findings Dealing with the Instructions

\begin{tabular}{clccc}
\hline \multirow{2}{*}{ Aspect } & \multicolumn{1}{c}{ Criteria } & \multicolumn{3}{c}{ Percentage (100\%) } \\
\cline { 3 - 5 } & & Yes & Partly & No \\
& The instructions are clear. & $93.33 \%$ & $6.67 \%$ & $0 \%$ \\
& The instructions are appropriate. & $100 \%$ & $0 \%$ & $0 \%$ \\
Instructions & The instructions are understandable. & $100 \%$ & $0 \%$ & $0 \%$ \\
& The instructions are confusing. & $0 \%$ & $00 \%$ & $100 \%$ \\
& The instructions are ambiguous. & $0 \%$ & $3.33 \%$ & $96.67 \%$ \\
& The instructions can be done by the & $96.67 \%$ & $3.33 \%$ & $0 \%$ \\
\hline & learners. & & & \\
\hline
\end{tabular}

Coverage of the Materials

The results of the try-out dealing with the coverage of the materials were also satisfactory. The data showed that they were understandable, and appropriate with the students' interest and needs. Furthermore, they were in line with the syllabus of the course, relevant to the goals of the course, matched the objectives of the course, covered both theoretical and practical points of view. It was proven by the scores given by the students (see Table 7). The table of qualification indicated that the quality of this aspect was excellent. Therefore, no revision was needed in respect to the coverage of this aspect.

Table 7 Findings Dealing with Coverage of the Materials

\begin{tabular}{|c|c|c|c|c|}
\hline \multirow{2}{*}{ Aspect } & \multirow{2}{*}{ Criteria } & \multicolumn{3}{|c|}{ Percentage $(100 \%)$} \\
\hline & & Yes & Partly & No \\
\hline \multirow{7}{*}{$\begin{array}{l}\text { Coverage of } \\
\text { the Materials }\end{array}$} & $\begin{array}{l}\text { The coverage of the materials is in } \\
\text { line with the syllabus of the course. }\end{array}$ & $90 \%$ & $10 \%$ & $0 \%$ \\
\hline & $\begin{array}{l}\text { The coverage of the materials is } \\
\text { relevant to the goals of the course. }\end{array}$ & $100 \%$ & $0 \%$ & $0 \%$ \\
\hline & $\begin{array}{l}\text { The coverage of the materials } \\
\text { matches the objectives of the course. }\end{array}$ & $100 \%$ & $0 \%$ & $0 \%$ \\
\hline & $\begin{array}{l}\text { The coverage of the materials covers } \\
\text { both theoretical and practical points } \\
\text { of view of English morphology. }\end{array}$ & $80 \%$ & $20 \%$ & $0 \%$ \\
\hline & $\begin{array}{l}\text { The coverage of the materials is } \\
\text { understandable. }\end{array}$ & $90 \%$ & $10 \%$ & $0 \%$ \\
\hline & $\begin{array}{l}\text { The coverage of the materials is } \\
\text { appropriate with the students' } \\
\text { interest. }\end{array}$ & $\begin{array}{c}83.33 \\
\%\end{array}$ & $10 \%$ & $6.67 \%$ \\
\hline & $\begin{array}{l}\text { The coverage of the materials is } \\
\text { appropriate with the students' } \\
\text { needss. }\end{array}$ & $90 \%$ & $10 \%$ & $0 \%$ \\
\hline
\end{tabular}




\section{Contents of the Materials}

The results of the try-out showed that the contents of the materials were clear, appropriate, understandable, high quality, well-designed, and up-to-date. In addition, they matched the goals and objectives of the course, and dealt with the learners' interests and needss. It was proven by the scores given by the students (see Table 8). The table of qualification indicated that the quality of this aspect was excellent. Therefore, no revision was needed in respect to this aspect.

Table 8 Findings Dealing with Contents of the Materials

\begin{tabular}{|c|c|c|c|c|}
\hline \multirow{2}{*}{ Aspect } & \multirow{2}{*}{ Criteria } & \multicolumn{3}{|c|}{ Percentage $(\mathbf{1 0 0 \% )}$} \\
\hline & & Yes & Partly & No \\
\hline \multirow{11}{*}{$\begin{array}{l}\text { Contents of } \\
\text { the Materials }\end{array}$} & The content of materials is clear. & $90 \%$ & $10 \%$ & $0 \%$ \\
\hline & $\begin{array}{l}\text { The content of materials is } \\
\text { appropriate. }\end{array}$ & 93.33 & $6.67 \%$ & $0 \%$ \\
\hline & $\begin{array}{l}\text { The content of materials is } \\
\text { understandable. }\end{array}$ & $96.67 \%$ & $3.33 \%$ & $0 \%$ \\
\hline & $\begin{array}{l}\text { The content of materials matches } \\
\text { with the goals of the course. }\end{array}$ & $100 \%$ & $0 \%$ & $0 \%$ \\
\hline & $\begin{array}{l}\text { The content of materials matches } \\
\text { with the objectives of the course. }\end{array}$ & $100 \%$ & $0 \%$ & $0 \%$ \\
\hline & $\begin{array}{l}\text { The content of materials matches } \\
\text { with the learners' interests. }\end{array}$ & $83.33 \%$ & $10 \%$ & $6.67 \%$ \\
\hline & $\begin{array}{l}\text { The content of materials matches } \\
\text { with the learners' needss. }\end{array}$ & $90 \%$ & $10 \%$ & $0 \%$ \\
\hline & $\begin{array}{l}\text { The content of materials is well- } \\
\text { designed. }\end{array}$ & $100 \%$ & $0 \%$ & $0 \%$ \\
\hline & $\begin{array}{l}\text { The content of materials is high } \\
\text { quality. }\end{array}$ & $90 \%$ & $10 \%$ & $0 \%$ \\
\hline & $\begin{array}{l}\text { The content of the materials has } \\
\text { covered the standard materials of } \\
\text { English morphology. }\end{array}$ & $80 \%$ & $20 \%$ & $0 \%$ \\
\hline & $\begin{array}{l}\text { The content of materials is up-to- } \\
\text { date. }\end{array}$ & $80 \%$ & $20 \%$ & $0 \%$ \\
\hline
\end{tabular}

\section{Language}

The results of the try-out showed that the language used was also clear, understandable, appropriate with students' English proficiency, and not confusing. It was proven by the scores given by the students (see Table 9). The table of qualification indicated that the quality of this aspect was excellent. Therefore, no revision was needed in respect to the language used. 


\begin{tabular}{clccc}
\hline \multirow{2}{*}{ Aspect } & \multicolumn{1}{c}{ Criteria } & \multicolumn{3}{c}{ Percentage (100\%) } \\
\cline { 3 - 5 } & & Yes & Partly & No \\
& The language used is appropriate with & $96.67 \%$ & $3.33 \%$ & $0 \%$ \\
Language & students' English proficiency. & $96.67 \%$ & $3.33 \%$ & $0 \%$ \\
& The language is clear. & $0 \%$ & $0 \%$ & $100 \%$ \\
& The language used is confusing. & $96.67 \%$ & $3.33 \%$ & $0 \%$ \\
\hline
\end{tabular}

Summaries

The results of the try-out showed that the summaries were clear, simple, understandable, well-organized, appropriate, and not confusing. It was proven by the scores given by the students (see Table10). The table of qualification indicated that the quality of this aspect was also excellent. Therefore, no revision was needed in respect to this aspect.

Table 10 Findings Dealing with the Summaries

\begin{tabular}{clccc}
\hline \multirow{2}{*}{ Criteria } & \multicolumn{3}{c}{ Percentage (100\%) } \\
\cline { 3 - 5 } & & Yes & Partly & No \\
& The summary is clear. & $96.67 \%$ & $3.33 \%$ & $0 \%$ \\
& The summary is simple. & $96.67 \%$ & $3.33 \%$ & $0 \%$ \\
Summaries & The summary is confusing. & $0 \%$ & $0 \%$ & $100 \%$ \\
& The summary is understandable. & $96.67 \%$ & $3.33 \%$ & $0 \%$ \\
& The summary is well-organized. & $96.67 \%$ & $3.33 \%$ & $0 \%$ \\
& The summary is appropriate with the & $100 \%$ & $0 \%$ & $0 \%$ \\
\hline & materials presented. & & & $0 \%$ \\
\hline
\end{tabular}

\section{CONCLUSIONS}

In short, it was concluded that the materials expected to solve the problems existing at Alauddin State Islamic University of Makassar had developed well. The researcher had developed good materials for the teaching of English morphology. It was done because of the cooperation between the researcher and advisors, experts, lecturers, as well as students.

The product was in the form of a textbook of English morphology. It consisted of 8 (eight) chapters - the number of pages for each chapter was varied: $8,15,16,17,15,19,20$, and 16 pages respectively. The total pages of the product were 126 pages. In addition, the materials accounted for introduction, morpheme, root, base, stem, affix, inflection, derivation, English words, word formation and other word formation processes. Furthermore, it was designed using Times New Roman theme font; meanwhile the letters were 13 point. For the title of each chapter was written using Cambria (Headings) font with 41 point; meanwhile for the 
sub-chapter was also written using Cambria (Headings) font but with different point (17) and style (title). In addition, the title of each chapter and sub-chapter were designed colorfully. Finally, in the title page of each chapter, the instructional objectives were provided colorfully.

\section{REFERENCES}

Anglin, J. M. 1993. Vocabulary Development: Morphological Analysis. Monographs of the Society for Research in Child Development. Chicago: University of Chicago Press.

Ghorbani, M. R. 2011. Quantification and Graphic Representation of EFL Textbook Evaluation Results. Theory and Practice in Language Studies, 1 (5), 511-520 (Online). Retrieved from http://ojs.academypublisher.com/index.php/tpls/article/view/0105511520/3084 on May $26^{\text {th }}, 2012$.

McGriff, S. J. 2000. Instructional System Design (ISD): Using the ADDIE Model. Penn State University. Retrieved from http://metalab.uniten.edu.my/ iskandar/project/july\%2009/ADDIE.pdf on May $6^{\text {th }}$, 2012.

Nunes, T., \& Bryant, P. 2006. Improving Literacy by Teaching Morphemes. New York: Routlege.

Nunes, T., Bryant, P., \& Olsson, J, 2003. Learning Morphological and phonological Spealling Rules: An Intervention Study. Scientific Studies in Reading, 7: 289-307.

Pressley, M., Disney, L., \& Anderson, K. 2007. Landmark Vocabulary Instructional Research and the Vocabulary Instructional Research that Makes Sense Now. In R. K. Wagner, A. E. Muse, and K. R. Tannembaum (Eds), Vocabulary Acquisition: Implications for Reading Comprehension (pp. 205 - 232) New York: Guilford Press.

Widyatmoko, F. X. L. 2011. Developing English writing materials for the tenth graders of SMAK ST. Albertus Malang. Unpublished Thesis of the Degree of Master of English Language Teaching. Malang: State University of Malang.

\section{APPENDIX}




\section{RUBRIC FOR EVALUATING THE DEVELOPED MATERIALS}

\begin{tabular}{|c|c|c|c|c|c|}
\hline No. & Aspects & Criteria & $\begin{array}{c}\mathrm{Ye} \\
\mathrm{s}\end{array}$ & Partly & No \\
\hline \multirow{3}{*}{1.} & \multirow{3}{*}{$\begin{array}{l}\text { Organizatio } \\
\mathrm{n} \text { of } \\
\text { materials }\end{array}$} & The materials are organized attractively. & & & \\
\hline & & $\begin{array}{l}\text { The organization of the materials in the form of } \\
\text { chapters is appropriate. }\end{array}$ & & & \\
\hline & & $\begin{array}{l}\text { The materials are organized in logically ordered } \\
\text { tasks. }\end{array}$ & & & \\
\hline \multirow{4}{*}{2.} & \multirow{4}{*}{$\begin{array}{l}\text { Instructional } \\
\text { objectives }\end{array}$} & The instructional objectives are clear. & & & \\
\hline & & The instructional objectives are understandable. & & & \\
\hline & & $\begin{array}{l}\text { The instructional objectives are ordered } \\
\text { appropriately. }\end{array}$ & & & \\
\hline & & The instructional objectives reflect to the topics. & & & \\
\hline \multirow{7}{*}{3.} & \multirow{7}{*}{ Examples } & The examples are clear. & & & \\
\hline & & The examples are understandable. & & & \\
\hline & & The examples are too easy. & & & \\
\hline & & The examples are too difficult. & & & \\
\hline & & The examples are confusing. & & & \\
\hline & & $\begin{array}{l}\text { The examples help learners to understand the } \\
\text { materials. }\end{array}$ & & & \\
\hline & & The examples deal with the theory. & & & \\
\hline \multirow{15}{*}{4.} & \multirow{15}{*}{ Exercises } & The exercises are understandable. & & & \\
\hline & & The exercises are clear. & & & \\
\hline & & The exercises are too easy. & & & \\
\hline & & The exercises are too difficult. & & & \\
\hline & & The exercises are appropriate. & & & \\
\hline & & $\begin{array}{l}\text { The exercises reinforce what learners have } \\
\text { already learned. }\end{array}$ & & & \\
\hline & & $\begin{array}{l}\text { The exercises present a progression from simple } \\
\text { to more complex. }\end{array}$ & & & \\
\hline & & The exercises are varied in format. & & & \\
\hline & & $\begin{array}{l}\text { The exercises match with the topic being } \\
\text { discussed. }\end{array}$ & & & \\
\hline & & The exercises challenge learners. & & & \\
\hline & & The exercises can be done by the learners. & & & \\
\hline & & $\begin{array}{l}\text { The exercises help the learners to comprehend } \\
\text { English word formation materials. }\end{array}$ & & & \\
\hline & & $\begin{array}{l}\text { The exercises help the learners to enhance their } \\
\text { ability to understand the theory of word- } \\
\text { structure. }\end{array}$ & & & \\
\hline & & $\begin{array}{l}\text { The exercises help the learners to improve their } \\
\text { ability in analyzing word-structure. }\end{array}$ & & & \\
\hline & & $\begin{array}{l}\text { The exercises help the learners to enhance their } \\
\text { ability in creating English word. }\end{array}$ & & & \\
\hline \multirow{2}{*}{5.} & \multirow{2}{*}{ Activities } & The activities are attractive. & & & \\
\hline & & The activities are appropriate with the students' & & & \\
\hline
\end{tabular}




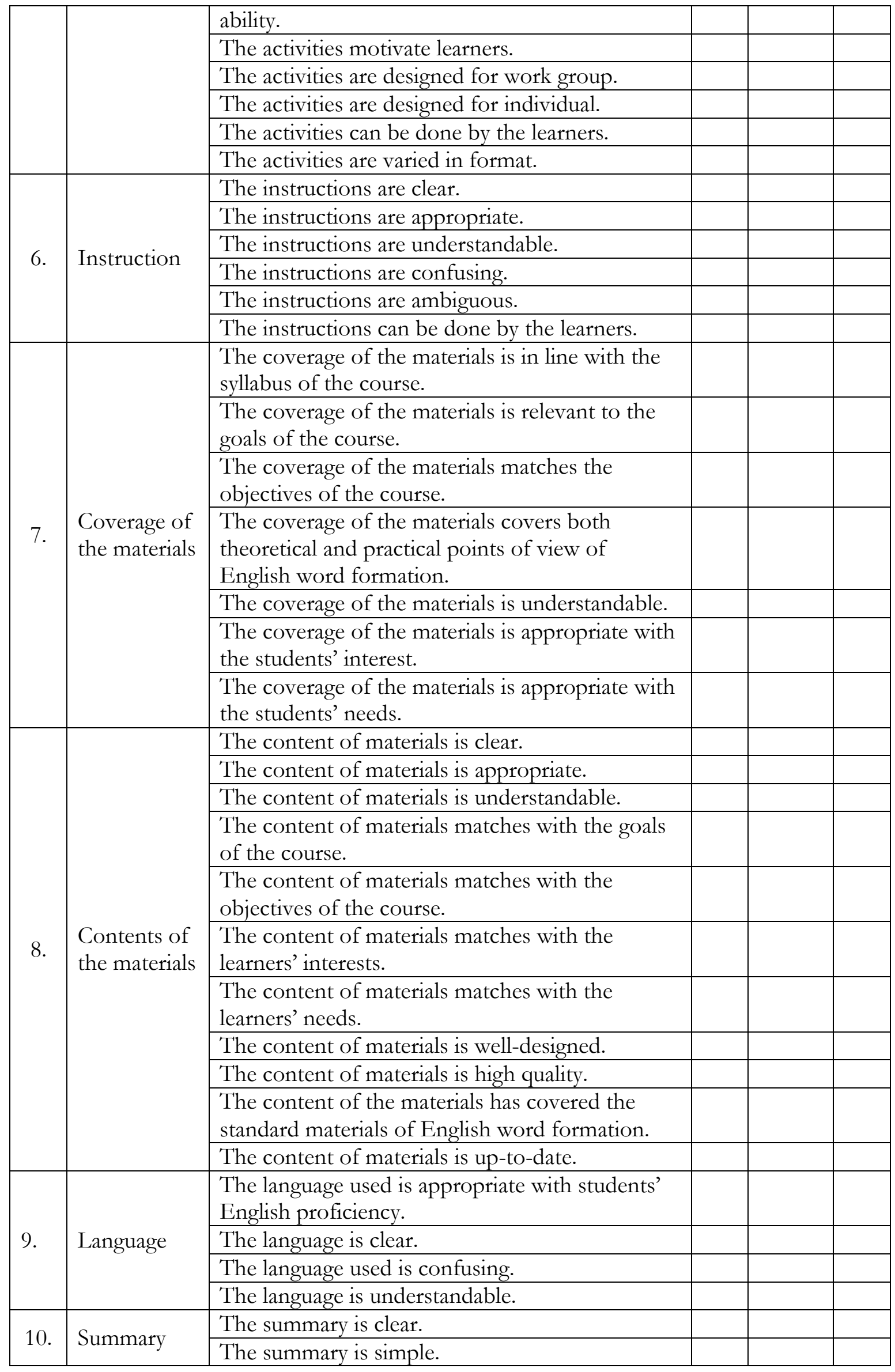




\begin{tabular}{|l|l|l|l|l|}
\hline & The summary is confusing. & & & \\
\hline & The summary is understandable. & & & \\
\hline & The summary is well-organized. & & & \\
\hline & $\begin{array}{l}\text { The summary is appropriate with the materials } \\
\text { presented. }\end{array}$ & & & \\
\hline
\end{tabular}

Adapted from:

Ghorbani, M. R. 2011. Quantification and Graphic Representation of EFL Textbook Evaluation Results. Theory and Practice in Language Studies, 1 (5), 511-520 (Online). Retrieved from http://ojs.academypublisher.com/index.php/tpls/article/view/0105511520/3084 on May $26^{\text {th }}, 2012$.

Widyatmoko, F. X. L. 2011. Developing English writing materials for the tenth graders of SMAK ST. Albertus Malang. Unpublished Thesis of the Degree of Master of English Language Teaching. Malang: State University of Malang. 